\title{
PEMETAAN POTENSI LAHAN PERTANIAN DI KABUPATEN TUBAN BERBASIS SISTEM INFORMASI GEOGRAFIS
}

\author{
Andik Adi Suryanto ${ }^{1)}$ Amaludin Arifia ${ }^{2)}$, Asfan Muqtadir ${ }^{3)}$, Dwi Kurnia Basuki ${ }^{4)}$ \\ andikadisuryanto@gmail.com ${ }^{1)}$,r35t4r34@gmail.com ${ }^{2}$, asfanme@gmail.com ${ }^{3)}$, dwiki74@gmail.com ${ }^{4)}$
}

\begin{abstract}
Abstrak
Kabupaten Tuban dengan luas lahan 183.994,56 ha berpotensi untuk mengembangkan usaha pertanian dibidang pangan, perkebunan dan tanaman hortikultura yang bertujuan untuk meningkatkan kesejahteraan petani serta meningkatkan kualitas dan kuantitas produksi yang akan mendorong kelancaran roda perekonomian. Peruntukan lahan pada sector pertanian seringkali bersaing dengan sektor lain seperti industry, pemukiman dan perdaganga. Meningkatnya kebutuhan lahan pertanian telah menimbulkan beberapa permasalahan yang berkaitan dengan pemanfaatan lahan. Hal tersebut disebabkan juga oleh kurangnya informasi yang berhubungan dengan produktifitas dan kelayakan penggunaan lahan tersebut. Dalam penelitian penelitian ini, akan dirancang suatu perangkat lunak yang dapat memberikan informasi pemetaan lahan pertanian di Kabupaten Tuban yang digunakan sebagai pengambilan informasi untuk analisa kebijakan bidang pertanian. Sistem ini dirancang menggunakan teknologi Webgis yaitu Map Server khususnya paket MS4W dengan menggunakan framework pmapper yang bekerja pada system operasi windows.
\end{abstract}

Kata kunci : Lahan pertanian, Webgis, Map Server, MS4W, Pmapper, Windows

\begin{abstract}
Tuban Regency with land area of 183,994.56 ha has the potential to develop agricultural business in the field of food, plantation and horticulture crops that aims to improve the welfare of farmers and improve the quality and quantity of production that will encourage the smooth running of the economy. Land use in the agricultural sector often competes with other sectors such as industry, settlement and trade. The increasing need for agricultural land has caused some problems related to land use. This is due to the lack of information related to the productivity and feasibility of the land use. In this research research, will be designed a software that can provide information mapping of agricultural land in Tuban Regency which is used as information retrieval for analysis of agricultural policy. This system is designed using Webgis technology that is Map Server especially MS4W package by using framework pmapper that work on windows operating system.
\end{abstract}

Keywords : Farmland, Webgis, Map Server, MS4W, Pmapper, Windows

ISSN Print $\quad$ : 1979-7141 


\section{Pendahuluan}

Sektor pertanian mempunyai peranan penting didalamnya, terutama kontribusinya terhadap lapangan kerja dan pangan dalam negeri. Dengan luas lahan 183.994,56 ha Kabupaten Tuban berpotensi mampu mengembangkan usaha pertanian dalam bidang pangan, perkebunan dan tanaman Hortikultura. Pertanian sebagai bagian tak terpisahkan dari pembangunan daerah Kabupaten Tuban yang bertujuan untuk meningkatkan kesejahteraan petani serta meningkatkan kualitas dan kuantitas produksi berbagai tanaman pangan sehingga akan mendorong kelancaran roda perekonomian. lebih efisien dan secara mudah untuk memberikan data dengan lebih cepat, yaitu dengan sistem penginputan data yang berbentuk struk data print out.

Dalam perkembangan pertanian tanaman pangan saat ini sangat erat kaitannya dengan permasalahan pemanfatan lahan, pengalihan guna lahan pertanian akan sangat mengancam luas lahan produksi pertanian seiring semakin lajunya roda pembangunan daerah yang semakin pesat. Pemanfaatan lahan pada sektor pertanian seringkali bersaing dengan sektor lain seperti industri, pemukiman dan perdagangan. Meningkatnya kebutuhan lahan pertanian telah menimbulkan beberapa permasalahan yang berkaitan dengan pemanfaatan lahan. Hal tersebut disebabkan juga oleh kurangnya informasi yang berhubungan dengan produktifitas dan kelayakan penggunaan lahan tersebut.

Sistem Informasi Geografis (SIG) merupakan salah satu sarana unttuk penyampaian informasi teriutama untuk informasi-informasi yang berhubungan dengan data spasial dan data pendukung penyampaian informasi lainnya. Penerapan Sistem Informasi Geografis (SIG) merupakan langkah yang tepat untuk pemetaan daerah penentuan peruntukan lahan pertanian. Telah diakui Sistem Informasi Geografis (SIG) mempunyai kemapuan yang sangat luas, baik dalam proses pemetaan dan analisa sehingga teknologi sering dipakai dalam proses perencanaan tata ruang. Teknologi GIS mengintegrasikan operasi pengolahan data berbasis database yang biasa digunakan saat ini, seperti pengambilan visualisasi yang khas serta berbagai keuntungan yang mampu ditawarkan analisis geografis melalui gambar-gambar petanya berbasis web.

Dalam penelitian ini, akan dirancang suatu Sistem Informasi Geografis yang dapat memberikan informasi Pemetaan Lahan Pertanian Di Kabupaten Tuban yang digunakan sebagai pengambilan informasi Untuk Analisa Kebijakan Bidang Pertanian. Aplikasi GIS yang dirancangakan menggunakan teknologi WEBGIS yaitu Map Server khususnya paket MS4W yang bekerja pada sistem operasi Windows.

\section{Kerangka Teori}

\subsection{Pertanian Tuban}

Kabupaten Tuban dengan luas 183.994,56 Ha berpotensi untuk pengembangan usaha pertanian tanaman pangan, perkebunan, peternakan, tanaman hortikultura dan usaha di bidang kehutanan terutama pembangunan hutan rakyat. Komoditi tanaman pangan yang banyak diusahakan adalah padi, jagung, kacang tanah, kacang hijau, kedelai, ubi kayu, ubi jalah dan jenis ubi-ubian lainnya. Komoditas diatas merupakan sumber pendapatan para petani yang perlu terus di dorong peningkatan produksi dan efisiensi usahanya guna meningkatkan pendapatan petani atau masyarakat pedesaan dan disamping itu untuk mencukupi berbagai permintaan produk permintaan.

\subsection{Strategi dan Arah Kebijakan}

Guna terwujudnya kemajuan pembangunan di sektor pertanian khususnya Komoditas Tanaman Pangan maka Bidang Tanaman Pangan Dinas Pertanian Kabupaten Tuban menetapkan Strategi dan arah kebijakan sebagai berikut :
a. Meningkatkan Produksi Tanaman Pangan;
b. Mengembangkan sistem ketahanan pangan;
c. Membangun Agribisnis melalui pengembangan SDM dan SDA; 
d. Pengamanan dan Penyelamatan produksi yaitu dengan jalan pengendalian hama terpadu;

e. Mengadakan pembinaan intensif terhadap kelembagaan tani;

f. Meningkatkan pengetahuan dan ketrampilan petani;

g. Pengembangan potensi lahan yang disesuaikan dengan tata ruang kabupaten;

h. Perluasan areal tanam melalui pengembangan irigasi;

i. Peningkatan produksi tanaman pangan melalui peningakatan mutu intensifikasi;

j. Pengembangan dan pengolahan hasil pertanian serta pemasarannya.

\subsection{Program Kegiatan Peningkatan Mutu}

Dari keseluruhan perencanaan tersebut dituangkan dalam bentuk program dan kegiatan sebagai berikut :
a. Pengadaan Pompa Air Sungai;
b. Pengadaan Air Pompa Sumur Bor;
c. Pengendalian Hama Penyakit Tanaman Pangan;
d. Promosi Atas Hasil Produksi Pertanian Unggulan Daerah;
e. Peningkatan Pasca Panen dan Pengolahan Hasil Pertanian;
f. Pembangunan Jalan Usaha tani;
g. Penyusunan Data Base Potensi Produksi Pertanian.

\subsection{Pmapper}

Pmapper merupakan salah satu framework atau tool yang dapat digunakan untuk membangun aplikasi pemetaan (SIG) yang berbasiskan layanan web. Framework ini telah dikembangkan oleh DM Solutions Group dengan tujuan untuk menghasilkan lingkungan kerja yang sangat customizable dan adaptable dalam pendistribusian dan pengelolaan aplikasiaplikasi web-mapping.

\subsection{Sistem Informasi Geografis}

GIS merupakan suatu alat yang dapat digunakan untuk mengelola (input, manajemen, proses, dan output) data spasial atau data yang bereferensi geografis. Setiap data yang merujuk lokasi di permukaan bumi dapat disebut sebagai data spasial bereferensi geografis. Misalnya, data kepadatan penduduk suatu daerah, data jaringan jalan suatu kota, data distribusi lokasi pengambilan sampel, dan sebagainya.

Sistem Informasi Geografis merupakan kombinasi manajemen database dalam mengumpulkan dan menyimpan sejumlah data geospasial yang besar, bersama-sama dengan kemampuan analisis spasial untuk mengetahui hubungan geospasial antara entitas dari masingmasing data yang digunakan, ditambah dengan peta layar yang berfungsi menggambarkan hubungan data geospasial dalam dua dan tiga dimensi dalam bentuk peta.

\subsection{MapServer}

MapServer adalah sebuah lingkungan pengembangan bersifat sumber terbuka (open source) untuk pengembangan aplikasi internet yang memungkinkan pengolahan spasial. Bisa dijalankan sebagai sebuah program CGI atau melalui Mapscript yang mendukung beberapa bahasa pemrograman. MapServer dulunya dikembangkan oleh Universitas Minnesota. MapServer asalnya dikembangkan dengan dukungan NASA, yang membutuhkan sebuah cara untuk membuat citra satelit mereka bisa tersedia untuk umum..

\subsection{Metodologi Pengembangan Sistem Informasi}

Metodologi adalah kesatuan metode-metode, prosedur-prosedur, konsep-konsep pekerjaan, aturan-aturan dan postulat-postulat yang digunakan oleh suatu ilmu pengetahuan, seni atau disiplin yang lainnya. Sedangkan metode adalah suatu cara, teknik yang sistematik untuk mengerjakan suatu. Metodologi pengembangan system berarti adalah metode-metode, prosedur- 
prosedur pekerjaan, aturan-aturan dan postulat-postulat yang akan digunakan untuk mengembangkan suatu system informasi.

Dalam suatua pengembangan system diperlukan, beberapa tahapan-tahapan mulai dari perencanaan sampai dengan penggunan system. Tahapan-tahapan tersebut dinamakan SDLC (System Development Life Cycle) secara garis besar siklus hidup pengembangan system ini terdiri dari :

1. Tahap Perencanaan

2. Tahap Analisis

3. Tahap Perancangan

4. Tahap Implementasi

5. Tahap Testing

6. Tahap Pemeliharaan

\section{Metodologi Sistem}

\subsection{Perangkat Pendukung}

Adapun alat yang digunakan untuk mendukung pengerjaan system Informasi Geografis ini spesifikasinya sebagai berikut :

a. Perangkat Keras (Hardware)

- Notebook Thinkpad X210e

- AMD E-350 (2 CPUs),

- Memori $2 \mathrm{~GB}$

- HDD $320 \mathrm{~GB}$

b. Perangkat Lunak (Software)

- Windows 7 Profesional 32-bit

- Quantum GIS 1.8.0 sebagai pengolah peta dan data spasial

- MS4W 3.0.6 sebagai Webgis Server

- Pmapper 4.3.1 sebagai Framework Webgis

- Artisteer sebagai pengembang Web Template

- PHP 5.4.0 sebagai Bahasa pemrograman webnya

- PostgreSQL 9.0 dan Postgis sebagai database

- Note

\subsubsection{Data Pendukung}

Data Raster Peta Wilayah dan penggunaan lahan Kabupaten Tuban serta data atribut pendukung lainnya seperti berikut :

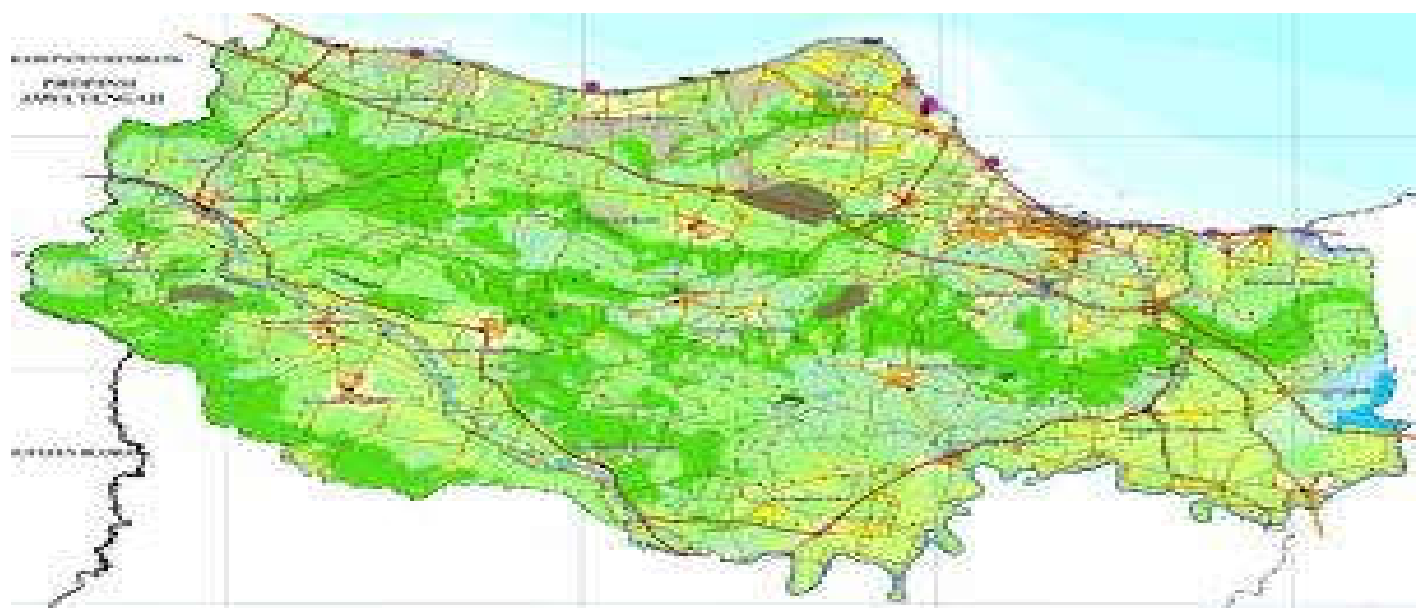

Gambar 1 Peta Pola Ruang RTRW Kab. Tuban (Sumber BAPPEDA Tuban) 
Tabel 1 sampel data produksi tanaman padi

\begin{tabular}{|c|c|c|}
\hline $\begin{array}{l}\text { Kecamatan } \\
\text { Sub Regency }\end{array}$ & $\begin{array}{c}\text { Luas Tanam } \\
\text { Planted } \\
\text { Area } \\
\text { (Ha) }\end{array}$ & $\begin{array}{c}\text { Luas Panen } \\
\text { Harvested } \\
\text { Area } \\
\text { (Ha) }\end{array}$ \\
\hline$(1)$ & $(2)$ & (3) \\
\hline 1. Kenduruan & 1.449 & 1.410 \\
\hline 2. Bangilan & 3.866 & 3.724 \\
\hline 3. Senori & 5.801 & 5.589 \\
\hline 4. Singgahan & 6.327 & 5.986 \\
\hline 5. Montong & 2.653 & 2.556 \\
\hline 6. Parengan & 4.292 & 4.128 \\
\hline 7. Soko & 6.198 & 5.764 \\
\hline 8. Rengel & 7.513 & 6.588 \\
\hline 9. Grabagan & 1.053 & 1.015 \\
\hline 10. Plumpang & 10.635 & 9.585 \\
\hline 11. Widang & 8.488 & 7.819 \\
\hline 12. Palang & 4.079 & 3.910 \\
\hline 13. Semanding & 1.834 & 1.764 \\
\hline 14. Tuban & 1.064 & 1.025 \\
\hline 15. Jenu & 3.295 & 3.121 \\
\hline 16. Merakurak & 6.333 & 5.983 \\
\hline 17. Kerek & 2.095 & 2.005 \\
\hline 18. Tambakboyo & 2.855 & 2.755 \\
\hline 19. Jatirogo & 3.344 & 3.235 \\
\hline 20. Bancar & 4.632 & 4.341 \\
\hline Jumlah/Tota/ 2012 & 87.806 & 82.303 \\
\hline
\end{tabular}

Tabel 2 Daftar jenis tanaman setiap komoditas

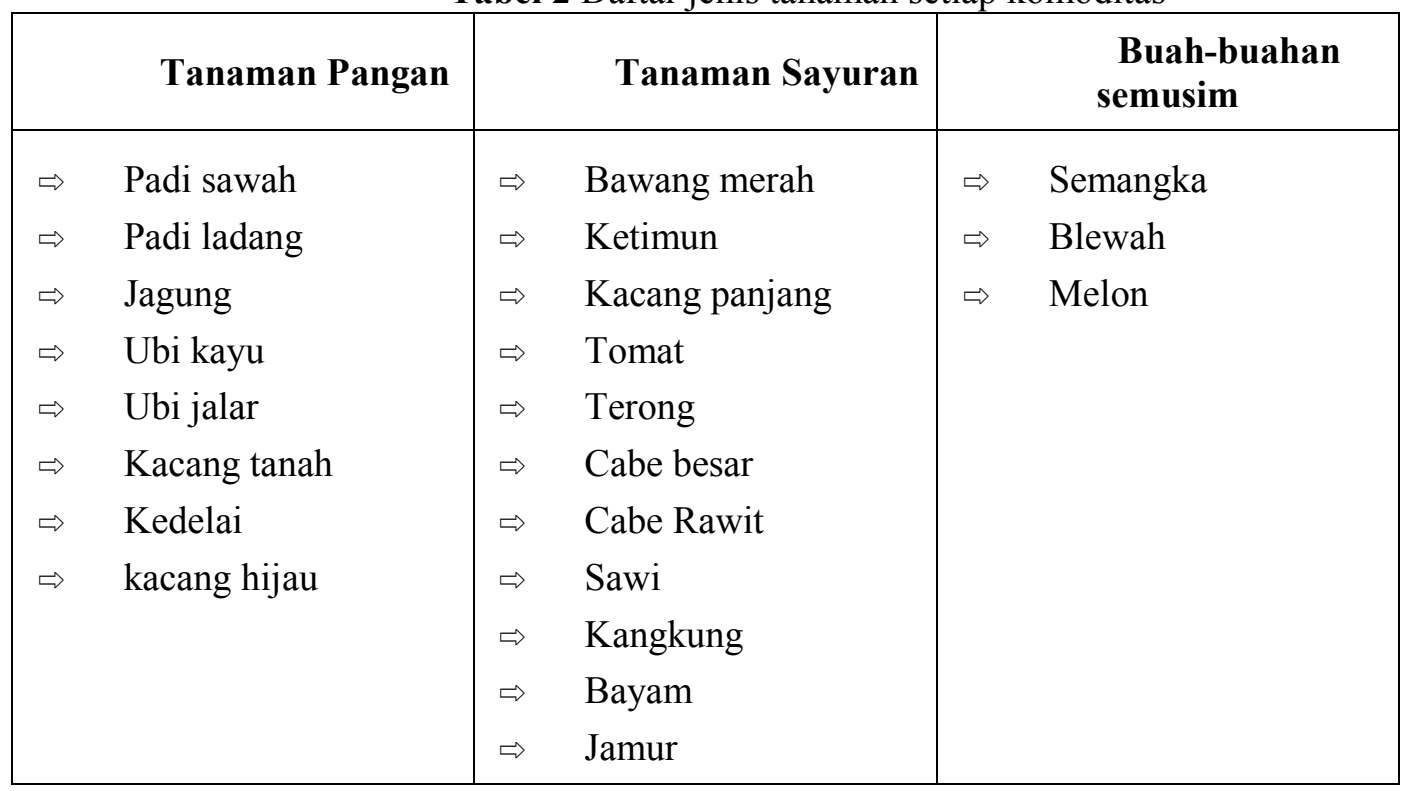

\subsection{Kerangka Sistem Informasi}

Kerangka sistem informasi merupakan gambaran fisik sebuah sistem informasi dimana terdapat beberapa data yang merupakan sebuah inputan dari sistem tersebut. Terdapat beberapa proses dan hasil keluaran berupa data yang di tampilkan dengan beberapa model penyajian. 


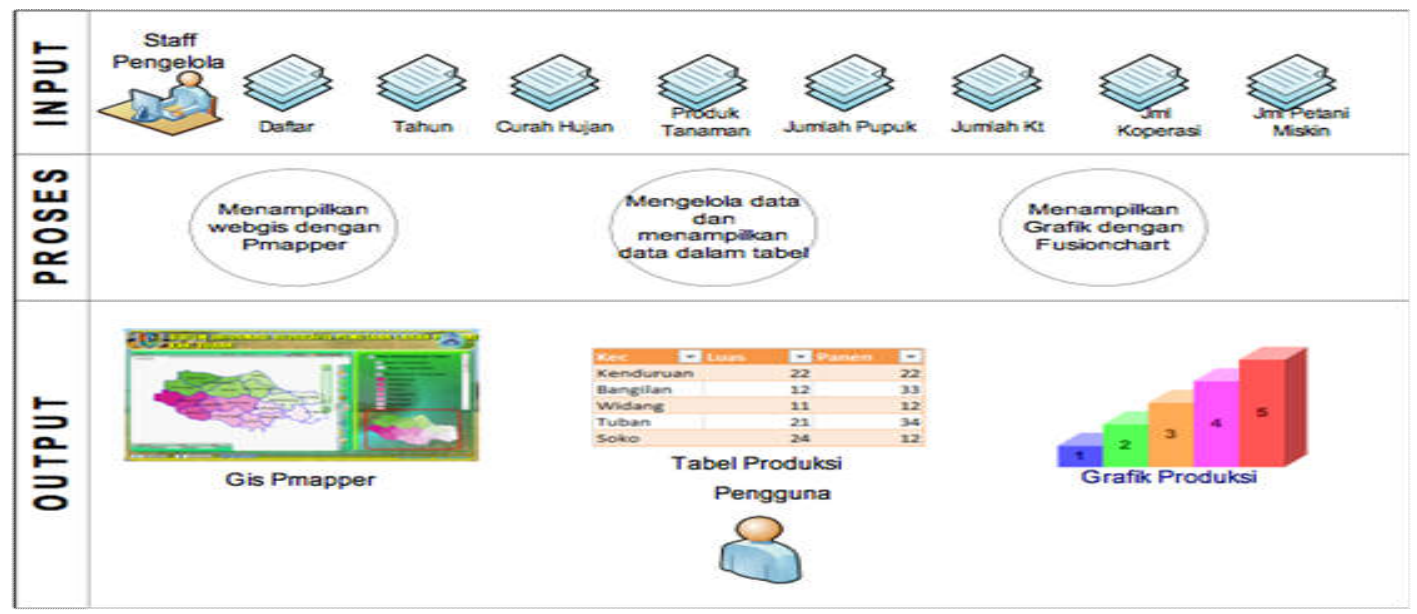

Gambar 2 Kerangka Sistem Informasi

\subsection{Desain Basis Data}

Pada tahapan awal dalam perancangan basis data ini adalah membuat pemodelan data konseptual yang akan dijadikan landasan untuk basis data, setelah didapat model basis data, maka pemodelan data konseptual tersebut diwujudkan dalam hubungan antar tabel menggunakan asosiasi sehingga didapatkannya model data relational.

CDM (Conceptual Data Model )digunakan untuk menggambarkan secara detail struktur basis data dalam bentuk logik. Berikut ini merupakan bentuk CDM dari desain basis data aplikasi sebagai berikut :

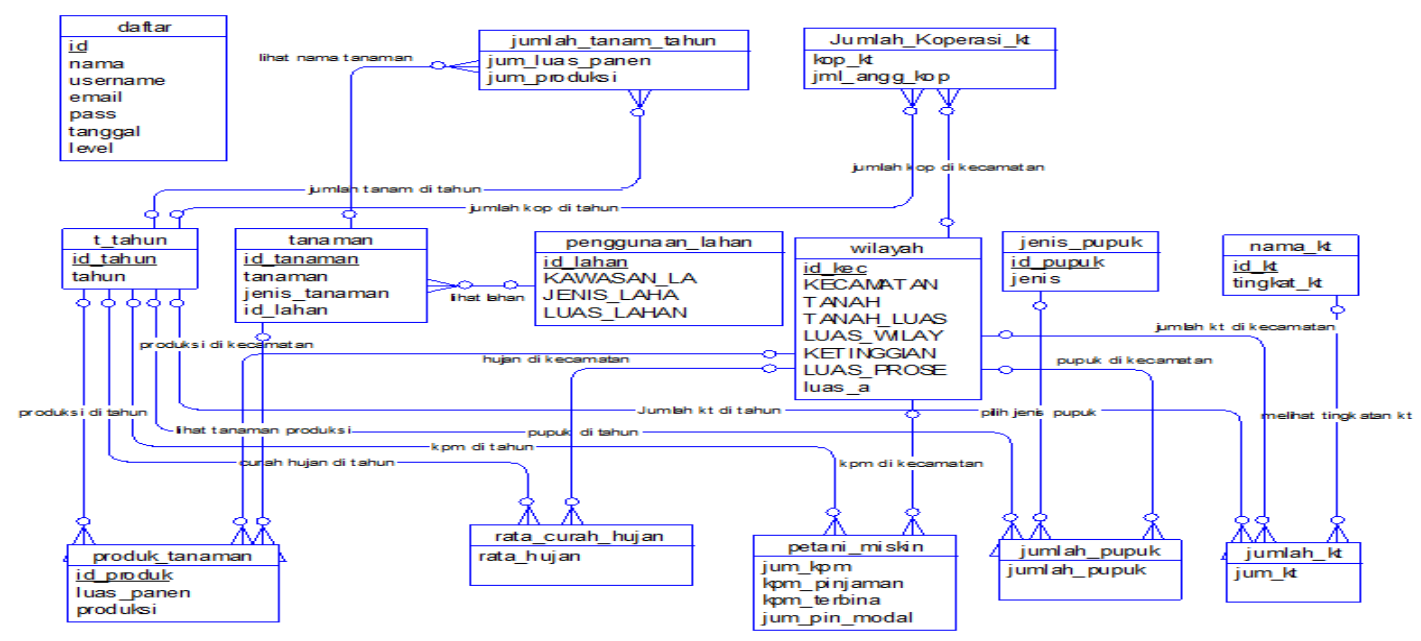

Gambar 3 CDM desain basis data

\section{Hasil dan Pembahasan \\ 4.1 Implementasi Sistem}

Dalam implementasinya, sistem ini dapat berjalan dengan baik pada Browser Mozilla

Firefox. Dalam pengujian menggunakan jaringan, sistem ini telah diujikan pada sistem operasi yaitu Microsoft Windows 7 Professional. Berikut ini merupakan gambar implementasi sistem pada browser Mozilla Firefox 27.0.1 dengan Resolusi 1366 x 768 pada layar monitor Netbook. 


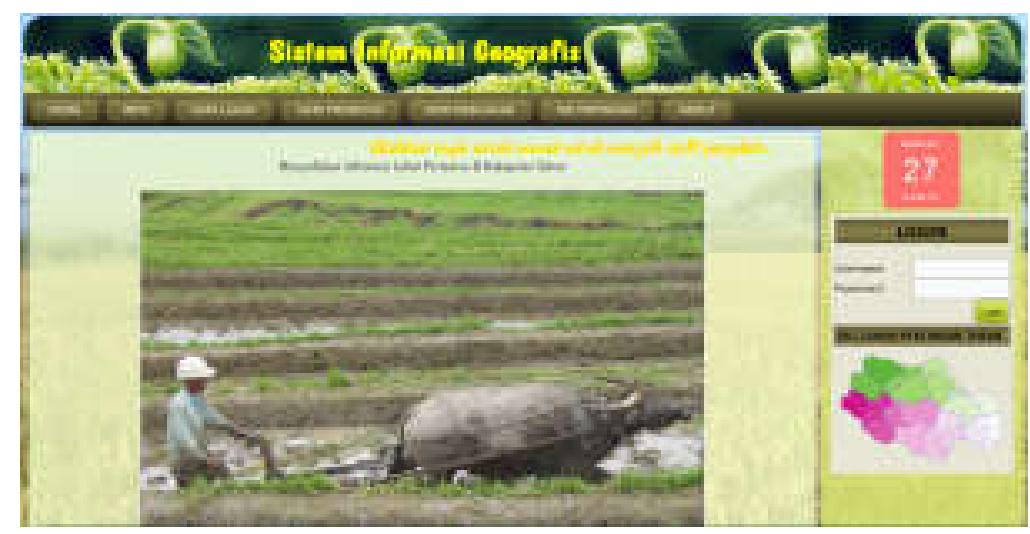

Gambar 4 Implementasi pada browser Mozilla

\section{Menu Home}

Pada gambar 5 merupakan tampilan awal pada saat pertama kali sistem ini di akses. Pada tampilan ini terdapat gambar slide show foto-foto dengan tema pertanian dengan tambahan widget kalender sehingga tampilan lebih menarik. Berikut ini adalah gambar tampilan dari menu Home.

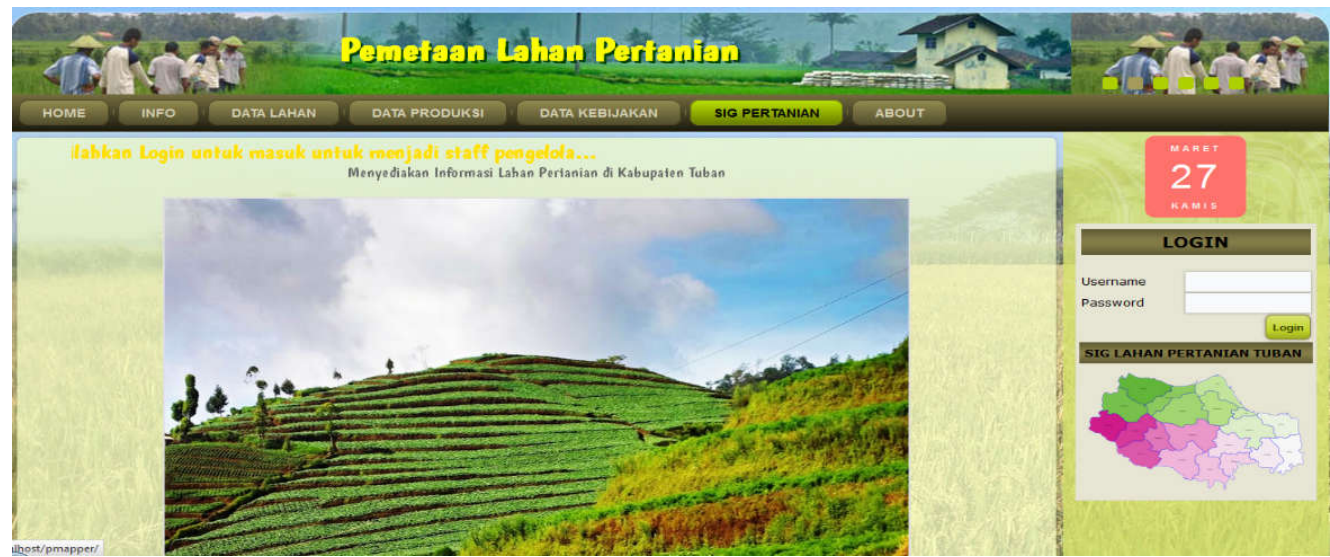

Gambar 5 Tampilan menu Home

\section{Menu Data Lahan}

Pada gambar 6 merupakan Menu data lahan terdapat dua sub menu yaitu sub menu Data Wilayah yang berfungsi menampilkan tabel Administrasi Wilayah Kabupaten Tuban. Sub menu Data Curah Hujan yang dapat menampilkan tabel Curah Hujan di setiap tahun di Kabupaten Tuban. Pada gambar adalah gambar tampilan pada sub menu Data Wilayah. 


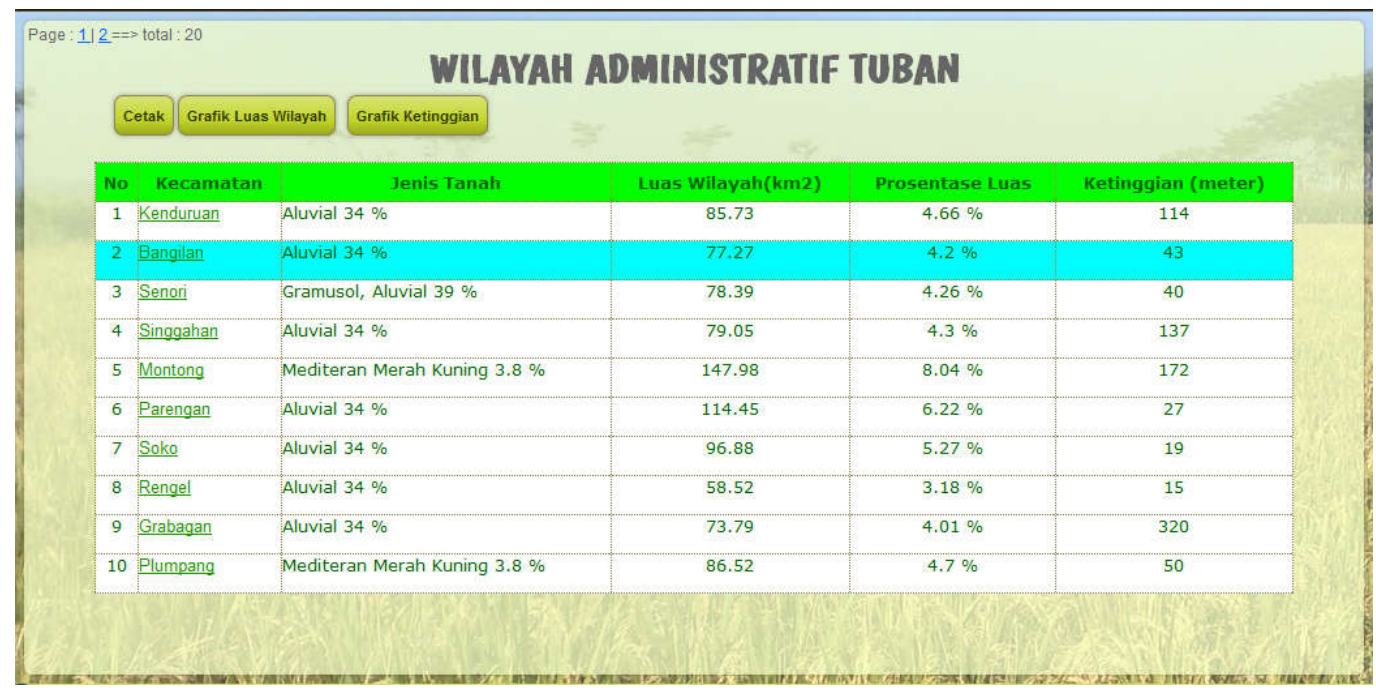

Gambar 6 Tampilan sub menu Data Wilayah

\section{Menu Data Produksi}

Pada Gambar 7 merupakan Menu data produksi terdapat dua sub menu yaitu sub menu Data Lahan Produksi yang berfungsi menampilkan tabel Data lahan pertanian tanaman pangan di kabupaten Tuban. Sub menu data produksi Tanaman yang dapat menampilkan tabel data produksi tanaman di Kabupaten Tuban. Berikut ini adalah gambar tampilan pada sub menu Data Lahan Produksi.

\begin{tabular}{|c|c|c|c|}
\hline \multirow[b]{2}{*}{ Cetak } & \multicolumn{3}{|c|}{ DATA LAHAN UNTUK PERTANIAN KAB TUBAN } \\
\hline & $=$ & & \\
\hline No & Jenis Lahan & Luas Lahan & Komoditas \\
\hline 1 & Tegalan & $30.001 \mathrm{Ha}$ & $\begin{array}{l}\text { + padi Ladang } \\
\text { - jagung } \\
\text { + ubi Kayu } \\
\text { + ubi Jalar } \\
\text { - kacang Tanah } \\
\text { + kedelai } \\
\text { + ketimun } \\
\text { + kacang Panjang } \\
\text { + tomat } \\
\text { - terong } \\
\text { + cabe Besar } \\
\text { - cabe Rawit } \\
\text { - bayam } \\
\text { + jamur }\end{array}$ \\
\hline 2 & Sawah & $56.308 \mathrm{Ha}$ & $\begin{array}{l}\text { - padi Sawah } \\
\text { kacang Hijau } \\
\text { - bawang Merah } \\
\text { sawi } \\
\text { sannam n }\end{array}$ \\
\hline
\end{tabular}

Gambar 7 Tampilan tabel data lahan produksi pertanian

Dalam tabel pada gambar 7 akan menampilkan jenis lahan pertanian untuk tanaman pangan yang terdapat berbagai tanaman yang dapat di tanam di lahan tersebut sesuai jenis tanaman yang dapat di tanam pada lahan di kabupaten Tuban.

\section{Menu SIG Pertanian}

Pada gambar 8 menampilkan peta batas administrasi dan lahan di kabupaten Tuban. Berikut ini tampilan awal Sistem Informasi Geografis pada framework pmapper. 


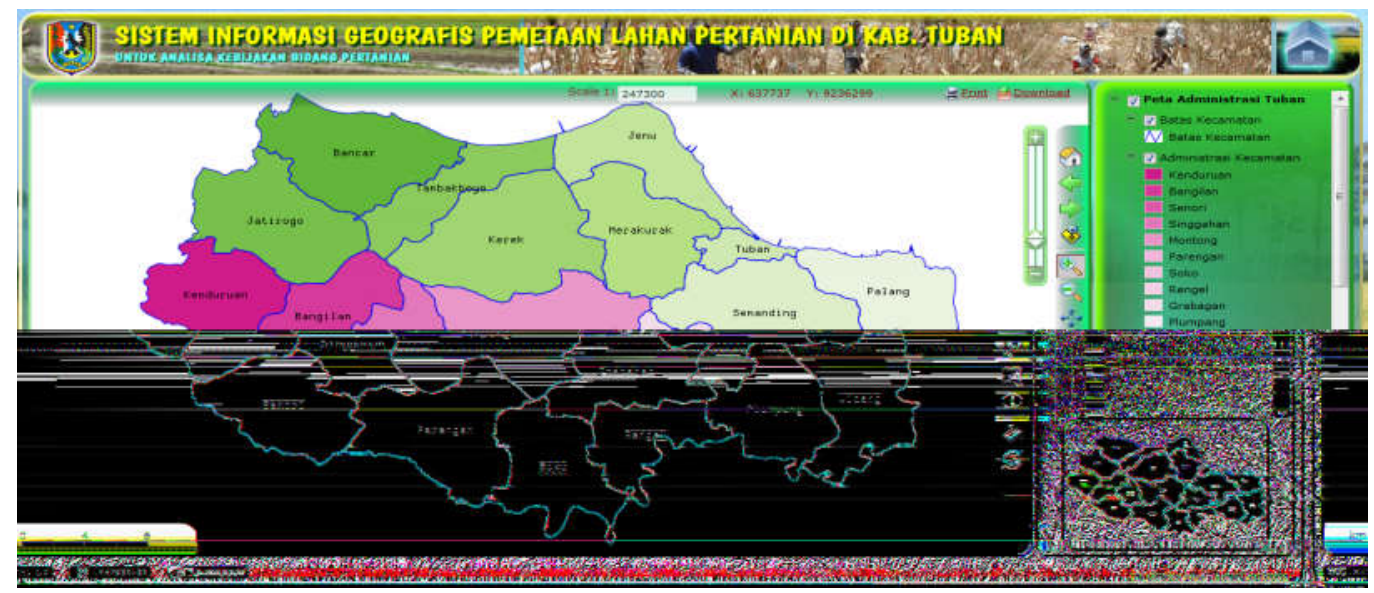

Gambar 8 Tampilan awal untuk menampilkan peta

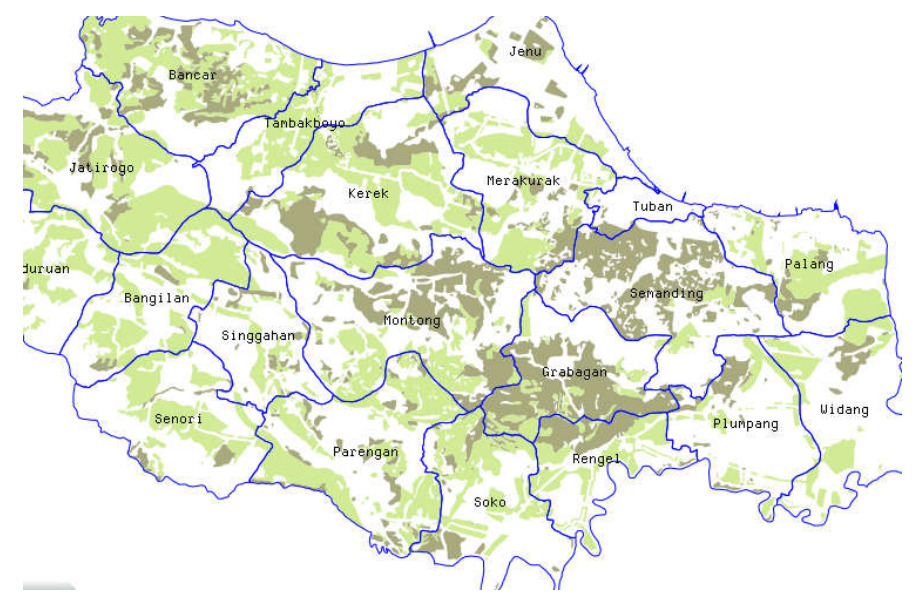

Gambar 9 Tampilan layer lahan pertanian pangan

Pada gambar 9 menampilkan peta lahan pertanian pangan yang sudah tergabung dari batas wilayah maupun data atribut antara penggunaan lahan umum dan batas desa sehingga data atribut akan menjadi lengkap.

\section{Penutup}

\subsection{Kesimpulan}

Berdasarkan analisa dan implementasi pada bab sebelumnya, maka dapat diambil kesimpulan bahwa :

1. Dengan menggunakan framework pmapper pada Sistem Informasi Geografis ini, data lahan dan data administrasi wilayah dapat di tampilkan dalam website yang interaktif sehingga akan lebih informatif.

2. Sistem Informasi Geografis ini dapat menjadi sarana untuk membantu Dinas Pertanian Kabupaten Tuban dalam membaca data perkembangan produksi yang digunakan untuk membantu analisa dalam menentukan kebijakan peningkatan produktifitas pertanian tanaman pangan di Kabupaten Tuban.

3. Dalam Sistem Informasi Geografis ini dapat mempermudah staff pengelola dalam menyajikan data perkembangan produksi setiap tahun dengan tampilan grafik yang informatif

\subsection{Saran}

Pengembangan Sistem Informasi Geografis sangat belum memenuhi sempurna dan masih memiliki keterbatasan dan kekurangan serta memerlukan perbaikan untuk meningkatkan 
fungsi pada sistem ini. Adapun saran yang kiranya dapat membantu sistem informasi geografis ini menjadi lebih baik adalah sebagai berikut :

Untuk pengembangan selanjutnya, agar sistem ini dapat menampilkan peta wilayah dan peta lahan yang bersifat dinamis, sehingga akan dapat mengukur perkembangan luas wilayah dan luas lahan secara periodik. Di harapkan data atribut pada layer dapat berhubungan atau menampilkan data produksi atau grafik produksi pada saat di tampilkan query. Sehingga penyajian data produksi akan lebih interaktif pada layer peta. Pengaktifan plugin searching pada pmapper akan sangat membantu dalam pencarian layer data spasial sehingga penyajian data akan lebih informatif.

\section{DAFTAR PUSTAKA}

Adiwijoto, Kusno, 2011. Rencana Strategis Tahun 2011 - 2016. Tuban : Dinas Pertanian Tuban BPS, 2013. Tuban Dalam Angka 2013. Tuban : Badan Pusat Statistik Tuban HM, Jogiyanto. 2005. Analisa dan Desain. Yogyakarta : ANDI OFFSET

Prahasta, Eddy.2006. Membangun Aplikasi Web-Based GIS dengan Mapserver. Bandung : Informatika.

Wayan, I Nuarsa, 2005. Belajar Sendiri Menganalisis Data Spasial denagn Arcview GIS 3.3 Untuk Pemula. Jakarta: PT. Media Komputindo 2014 http://tubankab.go.id/site/geografi/letak-luas-wilayah/, diakses pada 11 Maret http://id.wikipedia.org/wiki/Mapserver, diakses pada 21 Pebruari 2014 . http://id.wikipedia.org/wiki/Postgres, diakses pada 21 Pebruari 2014 . http://pmapper.net/, diakses pada 16 Maret 2014 . http://tubankab.bps.go.id/ , diakses pada 12 Pebruari 2014 